\section{Autobiographical remarks by Ronald W. Clark}

\author{
Introduced by Albert C. Lewis
}

IN AUGUST I 982 Clark agreed to try to satisfy my curiosity-and, I hoped, eventually the curiosity of others who admired his work-by responding in writing to some questions which I would send to him later that month. With apologies for a late response, in December he sent surprisingly detailed answers to all that $I$ had asked and volunteered to give even more. If $I$ had been a member of the Bertrand Russell Editorial Project at the time I would have asked specifically about his Russell biography, but most of his remarks are nevertheless relevant to it. It was, as I recall, at my first visit that Clark asked me if I knew a John Slater of Toronto who collected Russelliana and who also had brought him the malt whiskey we were enjoying. I believe Slater's description of Clark very accurately brings out what pleasures and surprises awaited a dinner guest at Io, Campden Street.

The questions posed were:

(I) Do you have rather specific criteria to apply before taking up a biographical subject? Are there famous modern scientists whose biographies you have decided not to write?

(2) You said it was your work relating to the Swiss alps that led in a natural way to scientific biographies, but what led you to your writing about the alps and alpinists?

(3) What subjects interested you in school? Did you do well in examinations? Did you go to university and, if not, do you regret not having done so?
(4) When and how did you first recognize your writing talent (school days or later)? Have you had mentors as a writer and, if so, who are they? Were there teachers who were particularly helpful? Were your parents an influence in taking up a writing career?

(5) In addition to background subjects for your books, have you taught yourself foreign languages?

(6) Have you answered questions like these before?

Clark's answers were:

(I) Yes. I prefer to spend my time studying a man (or woman) who has really changed the world/the course of history. There are, of course, exceptions. I wrote the life of the Rev. W.A.B. Coolidge, an American, because he was the greatest of all mountain historians, a subject which fascinated me. I wrote the life of Sir Edward Appleton because I wanted to see his papers (despite discovery of the Appleton Layer I doubt if he'd qualify as a man who changed the world).

A second factor is that the biography must be economically viable. I am not a member of any university, and I do not work for any newspaper. I write the occasional article, but it is occasional, and I rarely do any reviewing. I earn my living solely by writing books-quite an unusual occupation nowadays-and a biography (or any other book, for that matter) has to provide an advance sufficient to make the book worth while as a bread-earner. I doubt if this is a handicap to any serious extent, since the people in whom I am interested are just the people who are likely to attract a publisher.

People whom I have decided not to write about have been ruled out by other, purely practical, factors which I have not mentioned. There must either be a cache of new material available, or the time must be ready for a new assessment; and of course there is no point in embarking on a biography if one knows that someone else is already at work on the subject (a reason why some years ago I decided not to work on Rutherford).

(2) Roughly half a century ago I was walking down Whitehall when I saw in the window of Stanford's, the mapsellers, a little paperbound book called Rock-Climbing round London. This was a guide to the sandstone outcrops on the Surrey-Sussex border whose existence I knew nothing about. I investigated. I then went up to 
North Wales, the nearest "real rocks" to London, became interested in mountaineering and mountaineering history, went to the Alps, and so on. Tyndall, Saussure, etc. were the obvious links, and from them I became interested in the development of science itself.

(3) My main interest in school was leaving it. I was less bored with history than with most subjects which they tried to ram down me. As you will gather from this, I did not do well in examinations. I did worst of all in science, and got past my Matriculation by concentrating on Physics and letting Chemistry go entirely by the board.

I did not go to a university, but went from school straight into a very minor job on, of all things, The Chemical Age. Regrets at not having gone to a university, roughly equal the thankfulness. Although I wrote Queen Victoria's Bomb, I think considering the "if's" of history is rather a waste of time.

(4) I quite forget if I ever recognized any writing talent. I certainly never had any mentors. There were no masters at school who were especially encouraging, and my parents wanted me to go into a bank, finding it difficult to believe that anyone could make a living at writing.

(5) I was taught French at school, and being on the Continent during the last nine months or so of the war, kept this up. I failed to learn more than a smattering of German; but I can usually look at German material and judge whether I shall want it translated.

Incidentally, regarding what you call the background subjects for my books, I have found it of real value that I lack specialized knowledge; the result is that I usually know what questions to ask. I found this of great help when writing The Birth of the Bombstill the only book covering the subject in the way I did (published 1961). I was lucky in meeting some of the most able physicists in the business-just the people who could explain if they were questioned by the honestly ignorant.

(6) No. I don't remember having been asked questions like this before. I am probably not a very good example as I seem to have gone into professional writing as much by luck as by management. I think that one of the attractions of biography was the need to find out what makes certain people tick. I was also lucky. John
Baker of Phoenix House started his Living Biographies, 30,000word books for the seventeen-upwards age-groups, and I wrote brief lives of Cockcroft, Julian Huxley, Sir Mortimer Wheeler, Churchill and Montgomery. This led me, in a very elementary way, into the problems of biography. Then, after The Birth of the Bomb and The Rise of the Boffins, I was asked to write the life of Sir Henry Tizard, which threw me in at the deep end, as far as handling masses of archival material was concerned. (It also enabled me to study Lord Cherwell's papers in the days when very few people had done so; and I am now, I am pretty certain, the only person who has had full access to the papers of the wartime scientists, Tizard, Cherwell, Haldane, and Appleton-quite apart from a mass of comparable material.)

The Bertrand Russell Editorial Project McMaster University 